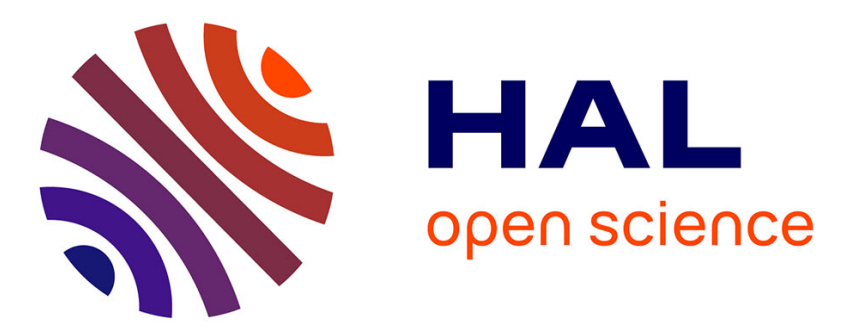

\title{
Size effects in CdS nanocrystals imbedded in glasses obtained by sol-gel route
}

\author{
Bernard Champagnon, M. Ferrari, L. Boudes, W. Granier
}

\section{To cite this version:}

Bernard Champagnon, M. Ferrari, L. Boudes, W. Granier. Size effects in CdS nanocrystals imbedded in glasses obtained by sol-gel route. Journal de Physique IV Proceedings, 1994, 04 (C4), pp.C4-615C4-615. 10.1051/jp4:19944165 . jpa-00252622

\section{HAL Id: jpa-00252622 https://hal.science/jpa-00252622}

Submitted on 1 Jan 1994

HAL is a multi-disciplinary open access archive for the deposit and dissemination of scientific research documents, whether they are published or not. The documents may come from teaching and research institutions in France or abroad, or from public or private research centers.
L'archive ouverte pluridisciplinaire HAL, est destinée au dépôt et à la diffusion de documents scientifiques de niveau recherche, publiés ou non, émanant des établissements d'enseignement et de recherche français ou étrangers, des laboratoires publics ou privés. 


\section{Size effects in CdS nanocrystals imbedded in glasses obtained by sol-gel route}

\section{B. CHAMPAGNON, M. FERRARI* L. BOUDES** and W. GRANIER**}

Physico-Chimie des Matériaux Luminescents, URA 442 du CNRS, Université Lyon I, 43 bd. du 11 Novembre 1918,69622 Villeurbanne, France

${ }^{*}$ C.N.R. Centro di Fisica degli Stati Aggregati ed Impianto Ionico, via Sommarive 14, 38050 Povo (TN), Italy

** Physicochimie des Matériaux, URA D 0407 du CNRS, Université Montpellier II, Place E. Bataillon, 34095 Montpellier, France

Quantum confinement effects in semiconductors are very extensively studied as the optical properties of the material can be modulated by size. Large non linearity coefficient and fast response time are expected in CdS nanocrystals. Among the technique used to prepare nanoparticles in a solid matrix the solgel route is promising as it allows different concentration, size and shape to be obtained.

$A$ bulk $\mathrm{Na}_{2} \mathrm{O}-\mathrm{SiO}_{2}-\mathrm{B}_{2} \mathrm{O}_{3}$ glass containing different amount of CdS was obtained by sol-gel route. Characterization by low frequency Raman scattering and absorption spectroscopy was performed in order to relate the optical properties to the size of the nanocrystals. The shift of the absorption band and the Raman scattering results confirm the formation of crystallites, with size below $20 \mathrm{~nm}$, in different samples. 